Historical Atlas of Central Europe,

Third Edition, Revised and Updated 



\section{Historical Atlas of \\ Central Europe}

Third Revised and Expanded Edition

Paul Robert Magocsi

University of Toronto Press Toronto Buffalo London 
The Historical Atlas of Central Europe is an extensively revised and updated version of the Historical Atlas of East Central Europe, which was published in 1993 by the University of Washington Press and the University of Toronto Press as Volume I in the series, "The History of East Central Europe."

The maps were compiled by Paul Robert Magocsi and drawn at the University of Toronto's Office of Cartography under the direction of Geoffrey J. Matthews and Byron Moldovsky.

Copyright (C) 1993, 2002 by the University of Washington Press Maps copyright (C) 1993, 2002, 2018 by Paul Robert Magocsi Copyright (C) 2018 by the University of Toronto Press

Printed in Canada

ISBN 978-1-4875-2331-2

All rights reserved. No part of this publication may be reproduced or transmitted in any form or by any means, electronic or mechanical, including photocopy, recording, or any information storage or retrieval system, without permission in writing from the publisher.

Publication cataloguing information is available from Library and Archives Canada.

University of Toronto Press acknowledges the financial assistance to its publishing program of the Canada Council for the Arts and the Ontario Arts Council, an agency of the Government of Ontario.

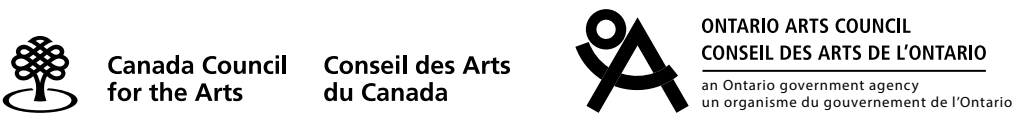

$\begin{array}{r}\text { Funded by the } \\ \text { Government } \\ \text { of Canada }\end{array} \begin{array}{r}\text { Fouvernemen parle } \\ \text { du Canada }\end{array}$ 
To my brother

Alexander Magocsi

for his wise counsel

throughout many years 
